\title{
Research on the Necessity of Constructing the Cooperative Education Mechanism between the Ideological and Political Education Teachers and Moral Educators in Fire Colleges
}

\author{
Jiangping Liu \\ Public Security Fire Force College, Kunming 650208, China
}

Keywords: Fire Academy, ideological and political work, moral education.

\begin{abstract}
Ideological and political work is the lifeblood of all work. The public security fire force academy is the cradle of fire police officers in the new period, shouldering the responsibility of transporting qualified fire commanders for the country. Strengthen the ideological and political education work, explore the ideological and political education professional teachers and moral education workers collaborative education mechanism construction, for school training excellent fire police officers indispensable.
\end{abstract}

\section{Introduction}

December 7, 2016 to 8, the General Secretary Xi in the ideological and political work conference stressed the University Ideological and political work in universities to cultivate what kind of people, how to cultivate and train people for whom this fundamental problem. To adhere to the moral education as the central link of the ideological and political work throughout the entire process of education, realize the whole process education, all-round education, and strive to create China's development of higher education in new situation. The new period military objectives and requirements of military cadres to understand the political, military Jianyou to do.

The public security fire force academy is the cradle of fire police officers in the new period, shouldering the responsibility of transporting qualified fire commanders for the country. School as the only fire forces academies, has been to build a fire education system to emergency rescue and fire command for the distinctive professional features, in personnel training, military management, teaching and research, foreign exchange has formed its own characteristics and ideas. But it is still at the exploring stage in the political moral education training, in view of the actual situation of the current situation of the development of higher occupation education in our country fire and the development of our school moral education for students, in-depth study of collaborative training mechanism, emphasizing moral education workers as the subject of Ideological and political education to enhance the ability and team construction, and the importance of system resources and make full use of the advantages. Teachers of Ideological and political education into the collaborative strength category, implementation and system optimization is crucial complementary advantages.

\section{Comply with the requirements of army construction and development and the growth requirements of fire police officers in the new period}

For a long time, ideological and political education has played an important role in the work of colleges and universities. As a military academy, the importance of Ideological and political education is beyond doubt. How to better realize the ideological and political education teaching work and the standardization of students' moral education, and find the appropriate point between them becomes particularly important. At present, the school moral education workers mainly have 
the political work of the organization, the participants, the commissar of the student team, the instructors and instructors. Among them, the student team is the main place for the students to study and live, and the professional water of their moral education influences the ideological and moral level of the students imperceptibly. Most of the ideological and political teachers work for daily teaching. How to give full play to the role of the two teams, and maximize the effect of Ideological and political education, we should think about the problem. At the same time, the development of army construction change rapidly, put forward new and higher requirements of the new era of fire officers ability and quality, and also to the ideological and political education of teachers and workers of moral education cooperative education mechanism put forward a huge challenge.

\section{We should deepen the reform of Ideological and political theory courses under the background of comprehensive reform}

"Our party has always held that the mastery of ideological education is the central link to unite the whole party in the great political struggle, and that ideological and political work is the lifeblood of economic work and all other work." In January 2015, general office of the CPC Central Committee, the State Council issued the "on Further Strengthening and improving university propaganda work under the new situation of opinion", reflects the CPC Central Committee attaches great importance to the ideological work in universities; on December 7, 2016 to 8, the General Secretary $\mathrm{Xi}$ in the ideological and political work conference stressed the University Ideological and political relations work in Colleges and universities to cultivate what kind of people, how to cultivate and train people for whom this fundamental problem. Teachers of Ideological and political theory course is the party's theory, line, principles and policies of the preacher, is the healthy growth of students and the guider "," moral education is students ideological and political education and daily management work of the organizers, practitioners and instructors". Although ideological and political education of Ideological and political education teachers and moral education workers have different approaches, but they are essentially the same, cooperative education research has a consistent goal base. Judging from the current situation of Ideological and political education in Colleges and universities, it is urgent to strengthen and improve the content and method of Ideological and political education in Colleges and universities.

\section{4. "Internet plus" era, the need of new media and traditional media's integration and development}

Information technology has penetrated all aspects of society. In the field of education, a disruptive revolution of information is taking place quietly. In the modern information society, the Internet has the characteristics of efficient, fast and convenient dissemination. How to adapt to the needs of fusion development of new media and traditional media Internet plus "era, to adapt to the rules of the ideological and political education, and strengthen the ideological mainstream media, spread positive energy has become a pressing matter of the moment in front of the ideological and political education workers. The ideological and political theory course teachers reasoning advantage than practical advantages; moral educators and students interact in a discourse system, the network is also handy, the deficiency is the relative lack of theoretical knowledge. We want to keep pace with the development and progress of science and technology, study the information network era teaching characteristics of political theory, in the development of the Internet, to open the line under the new position of the ideological and political education, complementary and teachers of Ideological and political education advantage, promote online teaching, and strive to create abundant information resources, technical means advanced study and training, evaluation, development of interactive communication and convenient network education platform. 


\section{The need of improving teachers' Ideological and political quality and educating ability under the view of multi value}

"Soldiers are ablaze, one will be ablaze, one nest", and the first-class fire command colleges and universities can not be separated from high-quality cadres, and the quality of cadres directly affects the quality of students. Over the years, the moral education workers facing responsibilities is not clear, the lack of professional knowledge and skills, the incentive mechanism is not perfect, the teachers of Ideological and political theory course is also facing the school often one-sided emphasis on teaching and scientific research, the teaching evaluation, thesis topic and evaluation of teachers' work as the important indicators and other issues, professional teachers of Ideological and political education the overall low level of participation of students, values and norms, moral education and concept, the lack of guidance, "the serious imbalance of intellectual education" and "moral education" in the balance. Under such system environment and personal value orientation, professional teachers lack the motive force to combine teaching with educating people, and there is no corresponding behavior measures. The education consciousness is not strong and the education responsibility is unknown. To strengthen the exchanges and cooperation between the two teams, is advantageous in the work of improving teachers' Ideological and political quality, improve the education ability, and student exchanges in education, develop a firm belief, noble morality, promoting the occupation development in scientific research to enhance occupation happiness.

\section{The proper aim of strengthening the army in the new period}

The new period military objectives and requirements of military cadres to understand the political, military Jianyou to do. School as the only fire forces academies, has been to build a fire education system to emergency rescue and fire command for the distinctive professional features, in personnel training, military management, teaching and research, foreign exchange has formed its own characteristics and ideas. But it is still at the exploring stage in the political moral education training, in view of the actual situation of the current situation of the development of higher occupation education in our country fire and the development of our school moral education for students, indepth study of collaborative training mechanism, emphasizing moral education workers as the subject of Ideological and political education to enhance the ability and team construction, and the importance of system resources and make full use of the advantages. Teachers of Ideological and political education into the collaborative strength category, implementation and system optimization is crucial complementary advantages.

The school responsible for the national transport of qualified fire commanders, realization of the ideological and political education teaching work and student moral education work standardized to better, it becomes to find point between the two is particularly important. As the main place for students to study and live, student team's professional water influences the ideological and moral level of students imperceptibly. The development of army construction change rapidly, put forward new and higher requirements of the new era of fire officers ability and quality, and also to the ideological and political education of teachers and workers of moral education cooperative education mechanism put forward a huge challenge.

To sum up, the ideological and political teachers and educators are complementary in Ideological and political education of students, their coordination is the theory and practice, students of the ideological and political education system and pertinence, and the effectiveness of ideological combination of objective needs and reflect reality. In order to strengthen the coordination and cooperation between professional teachers and moral educators, we should establish and improve the cooperative education mechanism of Ideological and political education in schools, and form a multi-level and all-round pattern of Ideological and political education. 


\section{References}

[1] Liu Lin, discussion on the cooperative education of Ideological and political education in Colleges and Universities -- Based on the perspectives of counselors and ideological and political teachers: theoretical observation, [J], 2015.10

[2] Li Weihong. Great efforts are made to explore the reform of the teaching methods of Ideological and political theory courses in higher education. [J].2014.1

[3] Shen Shen, Li Xiaoe. Research on synergetic effect of Ideological and political education and mental health education in universities, [J]. frontier, 2013.9 